REGULAR PAPER

H. Heinsen $\cdot$ M. Strik $\cdot$ M. Bauer $\cdot$ K. Luther

G. Ulmar · D. Gangnus · G. Jungkunz

W. Eisenmenger $\cdot$ M. Götz

\title{
Cortical and striatal neurone number in Huntington's disease
}

Received: 1 February 1994 / Revised, accepted: 3 May 1994

\begin{abstract}
The total cortical and striatal neurone and glial numbers were estimated in five cases of Huntington's disease (three males, two females) and five ageand sex-matched control cases. Serial $500-\mu m$-thick gallocyanin-stained frontal sections through the left hemisphere were analysed using Cavalieri's principle for volume and the optical disector for cell density estimations. The average cortical neurone number of five controls (mean age 53 \pm 13 years, range $36-72$ years) was $5.97 \times 10^{9} \pm 320 \times 10^{6}$, the average number of small striatal neurones was $82 \times 10^{6} \pm 15.8 \times 10^{6}$. The left striatum (caudatum, putamen, and accumbens) contained a mean of $273 \times 10^{6} \pm 53 \times 10^{6}$ glial cells (oligodendrocytes, astrocytes and unclassifiable glial profiles). The mean cortical neurone number in Huntington's disease patients (mean age $49 \pm 14$ years, range $36-75$ years) was diminished by about $33 \%$ to: $3.99 \times 10^{9} \pm 218 \times 10^{6}$ nerve cells $(P \leq 0.012$, MannWhitney U-test). The mean number of small striatal neurones decreased tremendously to $9.72 \times 10^{6} \pm$
\end{abstract}

Supported by a grant from the Deutsche

Forschungsgemeinschaft (He 1430/3-3)

H. Heinsen (区)

Morphologische Hirnforschung, Universitäts-Nervenklinik,

Füchsleinstrasse 15, D-97080 Würzburg, Germany

M. Strik

Pathologisches Institut, Josef-Schneider-Strasse 2,

D-97080 Würzburg, Germany

M. Bauer · K. Luther - G. Ulmar

Psychiatrisches Landeskrankenhaus Wiesloch, Postfach 1420,

D-69155 Wiesloch, Germany

D. Gangnus · G. Jungkunz

Nervenkrankenhaus des Bezirks Unterfranken, D-97816 Lohr, Germany

W. Eisenmengers

Institut für Rechtsmedizin der Universität, Frauenlobstrasse 7a, D-80337 München, Germany

M. Götz

Institut für Pathologie, Klinikum Aschaffenburg,

Am Hasenkopf, D-63739 Aschaffenburg, Germany
$3.64 \times 10^{6}(-88 \%)$. The decrease in total glial cells was less pronounced $\left(193 \times 10^{6} \pm 26 \times 10^{6}\right)$ but the mean glial index, the numerical ratio of glial cells per neurone, increased from 3.35 to 22.59 in Huntington's disease. Qualitatively, neuronal loss was most pronounced in supragranular layers of primary sensory areas (Brodmann's areae $3,1,2$; area 17 , area 41 ). Layer IIIc pyramidal cells were preferentially lost in association areas of the temporal, frontal, and parietal lobes, whereas spared layer IV granule cells formed a conspicuous band between layer III and V in these fields. Methodological issues are discussed in context with previous investigations and similarities and differences of laminar and lobar nerve cell loss in Huntington's disease are compared with nerve cell degen $\epsilon$ ration in other neuropsychiatric diseases.

Key words Huntington's disease - Human cerebral cortex $\cdot$ Striatum $\cdot$ Neurone number $\cdot$ Stereology

\section{Introduction}

Huntington's disease, a hereditary, autosomal dominant neurodegenerative disorder, is clinically characterized by the triad of motor disturbances, cognitive defects, and emotional disturbances [39]. Neuropathologically, Huntington's disease is diagnosed by bilateral degenerative changes in the striatum $[31,119]$ and nerve cell loss in this complex and functionally related structures [28, $74,75,79]$. Vonsattel et al. [120] proposed a simple procedure for the neuropathological grading of caudate atrophy. Myers et al. [86] correlated macroscopical grading of striatal atrophy and reduced nerve cell number with physical disability rating in a large sample of patients. The neurological signs are explained by nerve cell loss in the striate body. Choreic movements in early stages of Huntington's disease are believed to result from inhibition of the subthalamic nucleus [2] by selective degeneration of enkephalin-positive projection neurones directed to the globus pallidus externus [96], oculomotor disturbances from an interruption in the 
oculomotor-basal ganglia-thalamocortical circuit [3, 4], rigidity and bradykinesia from GABA imbalance in the globus pallidus externus/internus transmitter ratio [114]. On the other hand, early stages of Huntington's disease are frequently diagnosed as major depressive diseases, schizophrenia, or personality disorders in psychiatric institutions [39]. Psychiatric signs are known to precede movement disorders by years. The former clinical pictures are less well explained by neuronal degeneration in the striate body. It is argued that atrophy in the striate body disrupts the neuronal loop between prefrontal cortical regions and thalamic feedback $[3,4$, $71,85,98,115]$. Other investigators explain cognitive deficits by global cortical, subcortical, and white matter atrophy [28, 79], selective laminar loss of a nonphosphorylated neurofilament (SMI-32 ir) bearing pyramidal cells [25], and reduced nerve cell density in layers V and VI of the prefrontal cortex [108, 109]. In these investigations, nerve cell density estimations were thought to reflect total neuronal loss. This assumption has been shown to be problematic in ageing research $[15,30,38,70]$ as well as in the calculation of total astroglial number in Huntington's chorea [74] since complex agonal, post mortem, and technical factors are known to influence nerve cell density in an unpredictable manner. These factors cannot be compensated by strict protocols of fixation, embedding, and staining procedures. Therefore, our study is intended to supplement previous quantitative investigations by an unbiased estimation of total hemispheric nerve cell number using Cavalieri's principle for volume and the optical disector for nerve cell density estimation $[16,45$, $91,95,122,123]$.

\section{Materials and methods}

Five brains of patients with the clinical diagnosis of Huntington's disease (two females, three males) and five age- and sex-matched control brains without a history of neurological or psychiatric diseases were fixed in $4 \%$ formalin (one part of commercial $37 \%$ formaldehyde added to nine parts of tap water) for at least 3 months $[9,113]$. After removal of the meninges the brain stem and cerebellum were severed at the level of the rostral pons. The plane of section was perpendicular to the longitudinal axis of the brain stem. Both hemispheres were subdivided by a mediosagittal cut and the left hemispheres were pre-treated in ascending concentrations of glycerol-DMSO-formalin mixtures, embedded in gelatine, and soaked again in glycerol-DMSO-formalin mixtures. After these cryoprotective procedures [102], the embedded hemispheres were deep-frozen in $-60^{\circ} \mathrm{C}$ isopentane and serially sectioned on a Tetrander (Jung, Nussloch) at $600-700 \mu \mathrm{m}$ thickness. Section thickness cannot be directly read from the microtome. It must be optically determined in unstained as well as stained sections (for details see [58]). Due to staining, dehydration, and mounting procedures section thickness linearly decreases by about $20 \%$ to $480-540 \mu \mathrm{m}$. The slices were alternatingly collected in three plastic boxes and stored in $4 \%$ formalin. For routine and quantitative examinations each third section from the fronto-parallel series was Nissl stained with gallocyanin. Details of the staining and mounting procedures are given elsewhere $[10,54]$. Small tissue samples (maximally $30 \times 15 \mathrm{~mm}$ ) of the first frontal gyrus (Brodmann's area 8), of the head of the caudate nucleus rostral to the anterior commissure, and of the ventral striatum at the level of entrance of the anterior perforating arteries were dissected from the parallel formalin-fixed but unstained serial sections. These tissue segments were dehydrated, paraffin embedded and stained with van Gieson stain [101] and Gallyas' silver impregnation for the demonstration of fibrous astroglia [41]. Slides were coded and diagnosed without knowledge of the clinical history.

An additional unstained thick frozen section was taken at the level of the rostral lateral geniculate body and stained by a modified Gallyas technique [55] to exclude senile changes.

The quantitative composition of serial gallocyanin-stained and parallel unstained sections was determined by point counting methods. For this a transparent square lattice test system [121], consisting of coarse test lines spaced at $12 \mathrm{~mm}$, was laid upon the unstained and parallel stained sections. Each square of coarse test lines was subdivided by 16 finer test lines spaced at $3 \mathrm{~mm}$. The coarse and fine crossing lines formed the centre points. The number of coarse centre points or hits that fall on to either cortex or white matter yield a simple estimation of the quantitative composition of the cerebral hemispheres. The number of hits or points (Pp) multiplied by the area of the coarse squares $\left(d^{2}=12 \times 12\right.$ $\mathrm{mm}=144 \mathrm{~mm}^{2}$ ), the section thickness, and the factor $\mathrm{k}$ yield the volumes of cortex and white matter of unstained and gallocyanin stained cerebral hemispheres. The factor $\mathrm{k}$ indicates the spacing of serial sections. It was three in our investigation since we used every third section for the quantitative analysis.

The volume of stained hemispheres divided by the volume of unstained hemispheres yields the shrinkage factor $\left(\mathrm{s}_{\mathrm{f}}\right)$. Nerve cell density of stained sections multiplied by the shrinkage factor yields the nerve cell density of the fresh volume (or in vivo nerve cell density) assuming reversal of initial swelling of the nervous system after prolonged (at least 3 months) formalin fixation [9, 113].

The volumes of subcortical structures including striatum, claustrum, nuclear complex of thalamus, and amygdaloid bodies were likewise estimated. The number of hits of crossing points of the fine lines was used for analysis of the subcortical nuclear volume. Note that $\mathrm{d}^{2}$ in this case is $3 \times 3=9 \mathrm{~mm}^{2}$.

To obtain the total cell number within a reference volume (cortex or subcortical nuclei), the average nerve cell density must be multiplied by the volume of the cortex or subcortical nuclei. Braendgaard et al. [16] proposed a simple procedure to obtain an unbiased estimation of nerve cell density in the human cerebral cortex. In analogy with Braendgaard et al. [16] each fourth gallocyanin-stained section was centred onto a circle. This circle was subdivided by 30 beams (numerated clockwise from $0-29$ ) radiating at angles of $12^{\circ}$ from the centre of the circle. A random number between 0 and 29 was generated by a computer program and the course of the beam, e.g. 5 , running through the cortex was marked by ink on the microscope slide. The ensuing section was likewise centred onto the circle and the course of the next beam, in this case 6 , penetrating the cortex was traced by ink on this microscope section. The procedure was repeated going clockwise from 5 to 29 or, in larger brains, continuing the cycle from 0 passing all beams of the circle. Thus, a helical, systematically random probing of nerve cell density is achieved. Neo-, periarchi-, and archicortical regions were analysed without further subdivision.

The cortical nerve cell density was determined at higher magnification. A combination of a high power (Planapo oil immersion $40 / 1.0$ ) objective and a $5 \times 5 \mathrm{~mm}$ ocular grid subdivided by $10 \times 10$ lines inserted into a widefield $(10 \times)$ eyepiece were used. A random number 1, 2 or 3 was generated by a computer program. If random number 1 was selected, we started nerve cell density determinations in the molecular layer. Going strictly parallel to the ink line painted onto the microscope slide the visual field was moved $0.375 \mathrm{~mm}$ into the cortex and the nerve cell number was counted again. This procedure was repeated until the visual field fell outside the cortical boundaries. If random number 2 appeared, the visual field was moved $0.125 \mathrm{~mm}$ below the pial surface and nerve cell number counting was started in layer II. The visual fields were then moved by $0.375-\mathrm{mm}$ intervals through the cortex until the visual field fell into the medullary layer. For random number 3 , the visual field was shifted by $0.25 \mathrm{~mm}$ into the 
cortex (or upper layer III) prior to nerve cell density counting. Nerve cell density of the adjoining deeper parts of the cortical ribbon were counted at $0.375-\mathrm{mm}$ intervals identical to the procedures described above. Depending on the random number, the starting points of nerve cell density counting were systematically permutated from $1,2,3,1,2,3 \ldots, 3,1,2,3,1,2 \ldots$ or $2,3,1,2$, $3,1 \ldots$ following individual beams penetrating the cortex. These procedures guarantee a homogeneous unbiased estimation of nerve cell densities. At variance with Braendgaard et al. [16] who had to re-embed, cut, and stain wedges from their $7-\mathrm{mm}$ cortical slabs, we could record nerve cell density directly from our 0.48 - to $0.54-\mathrm{mm}$-thick gallocyanin-stained sections without further histological processing.

Nerve cell density was obtained with the optical disector. This method allows an unbiased estimation of cell densities $[16,45,91$, $95,122,123]$. We counted all neuronal nucleoli of large nerve cells or all neuronal nuclear profiles of small nerve cells $\left(Q_{i}\right)$, respectively, that came anew into the visual field $\left(F_{i}\right)$ after focusing on superficial parts of the sections. For this purpose, the fine adjustment knob of the microscope was mechanically stopped after optically penetrating the section for $29.7 . \mu \mathrm{m}$. An average of 250 optical fields with an average of 700 neuronal profiles per case were counted. The quotient $\mathrm{Q}_{\mathrm{i}} / \mathrm{F}_{\mathrm{i}}$ yields the average nerve cell density.

Granule cells were distinguished from cortical astrocytes by their oval nucleus and the presence of a small basophilic cytoplasm. Nevertheless, it was not always possible to decide whether a nuclear profile belonged to a reactive astrocyte, to a small layer II or layer IV granule cell, or to an otherwise unspecified interneurone. These nuclear profiles were recorded as unidentified cell types.

Nerve cell density in the striatum was counted by a slightly different procedure. Pairs of random numbers $1-4$ or $0-3$ were generated by a computer program. These random numbers were associated with the axes of an imaginative Cartesian system, the $y$ axes (random number 0-3) of which ran parallel to the ventricular surface of the caudate nucleus. The x-axes (random number 1-4) pointed in medio-lateral direction (Fig. 1). If random number pairs $0 / 1$ were selected, nerve cell density was counted in the dorsomedial part of the caudate nucleus. After this, the mechanical stage of the microscope was parallelly moved $2 \mathrm{~mm}$ on the $\mathrm{x}$-axis. If the visual field was within the boundaries of the caudate nucleus, nerve cell density was again determined, if not, the mechanical stage was moved an additional $2 \mathrm{~mm}$ in lateral direction until the visual field hit either striatal cell bridges or neurones of the dorsomedial putamen. In the absence of the putamen, the mechanical stage was moved $2 \mathrm{~mm}$ ventrally and then $2 \mathrm{~mm}$ medially until the microscope field fell within the caudate boundaries. These mediolateral and dorsoventral 2-mm steps provide a
Fig. 1 Striatum of a 46-year-old female control case (Acc nucleus accumbens; $v P$ ventral putamen)

Fig. 2 Striatum of a 41-year-old female Huntington's patient. Pallor of caudate nucleus and putamen. Conspicuous and typical about $0.5-\mathrm{mm}$-wide subventricular strip (arrows) which is completely devoid of neurones. Numerous tenuous fibre bundles are piercing both striatal nuclei. At variance with the normal controls, these fibre bundles contain an abundance of intensely basophilic oligodendrocytes that render these bundles visible at low-power magnification. Cell density in the nucleus accumbens $(A c c)$ is less reduced than in the dorsal parts of the striatum. $B a r=1 \mathrm{~mm}$

systematic random probing of visual fields within the striatal components of one section. In the subsequent section, the coordinates of the starting point were enhanced by one $(1 / 2$ instead of $0 / 1$ ) and neurone density was counted similar to the procedure described above. These steps were repeated until random number pairs $0 / 4$ were achieved after four consecutive sections. In the fourth section, the sampling cycle was started again at the dorsomedial parts of the caudate nucleus. This sampling scheme provides an unbiased cell density estimation throughout the striatum.

Nucleoli of small striatal neurones were counted with the optical disector described above using the same objective/eyepiece combination. Nuclear profiles of astrocytes were recognized by their fine, evenly distributed heterochromatin granules. Nuclear profiles of oligodendrocytes were smaller than astrocytic profiles, frequently clustered either within fibre fascicles or encountered as perineuronal satellites. Nevertheless, a precise classification of glial cells was impossible in gallocyanin stained sections. Equivocal profiles were assigned unidentified cells in Table 4.

The precision (see $\mathrm{CE}_{\mathrm{Ni}}$, Table 4 ) of the quantitative procedure can be calculated from $P_{i}, Q_{i}$ and $F_{i}$ of the individual serial sections [124]. Selected data were subjected to Mann-Whitney Utests at the "Rechenzentrum der Universität Würzburg".

\section{Results}

\section{Clinical data and course of the disease}

The clinical data as well as onset and duration of overt neurological signs are summarized in Table 1 . Notably, only one of the patients (male, aged 40 years) exhibited neurological signs from the beginning of the disease

Table 1 Summary of clinical data and neurological signs

\begin{tabular}{|c|c|c|c|c|}
\hline $\begin{array}{l}\text { Age } \\
\text { (years) }\end{array}$ & Sex & $\begin{array}{l}\text { Family } \\
\text { history }\end{array}$ & Anamnesis & $\begin{array}{l}\text { Age of onset/ } \\
\text { duration of } \\
\text { neurological signs }\end{array}$ \\
\hline
\end{tabular}

36 Female Yes $\quad$ Elementary school with good results; apprenticeship not completed; several

24 years $/ 12$ years jobs; married; 1983 diagnosis schizophrenia-like psychosis associated with probable Chorea Huntington

40 Male Yes $\begin{aligned} & \text { Elementary school; completed apprenticeship; predominantly neurologica } \\ & \text { signs, inability to perform manual skills and to continue his job; suicidal } \\ & \text { behaviour at the age of } 35\end{aligned}$

41 Male Yes Elementary school; completed 3-year-apprenticeship at the German Federal Post Offices and occupation at this institution for 2 years; thereafter various jobs, alcoholism, promiscuity; confined for fraud and theft to several years of imprisonment; confined to State Psychiatric Hospital at the age of 36 ; manic-

$\begin{array}{lll}54 & \text { Female } \quad \text { Yes } & \begin{array}{l}\text { depressive episodes, nocturnal agression, progressive dementia } \\ \text { Housewife; married; at the age of } 30 \text { change of personality, aggressive and } \\ \text { paranoid behaviour }\end{array} \\ \text { Male } & \text { Possible } \begin{array}{l}\text { Tram driver; had to resign from his occupation by neglect of red traffic signal } \\ \text { at the age of 54; disturbance of concentration and memory, aggression, } \\ \text { paranoid ideation }\end{array}\end{array}$
depressive episodes, nocturnal agression, progressive dementia

29 years/11 years

29 years/12 years

36 years (?)/

18 years

65 years $/ 7$ years paranoid ideation 


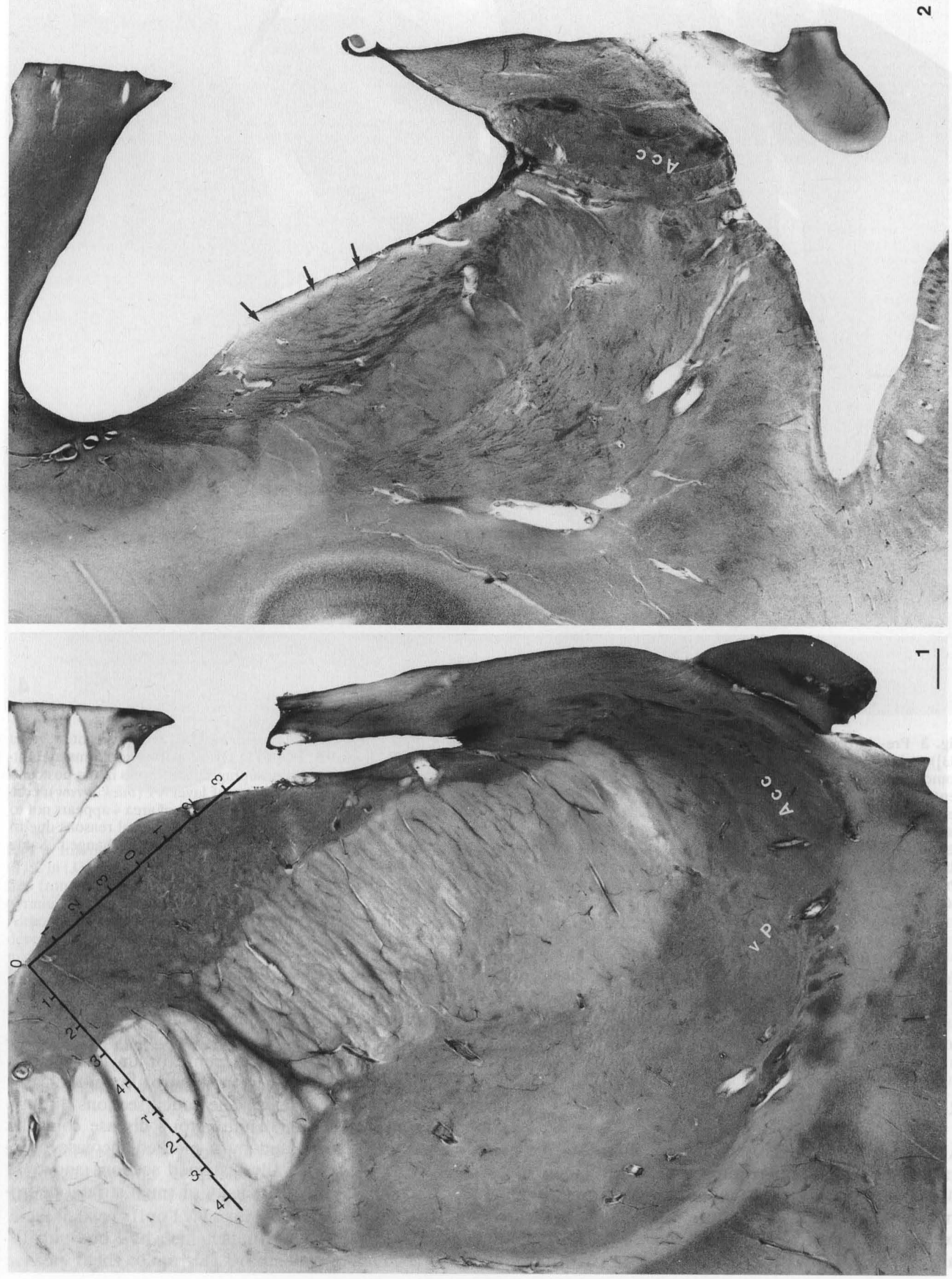




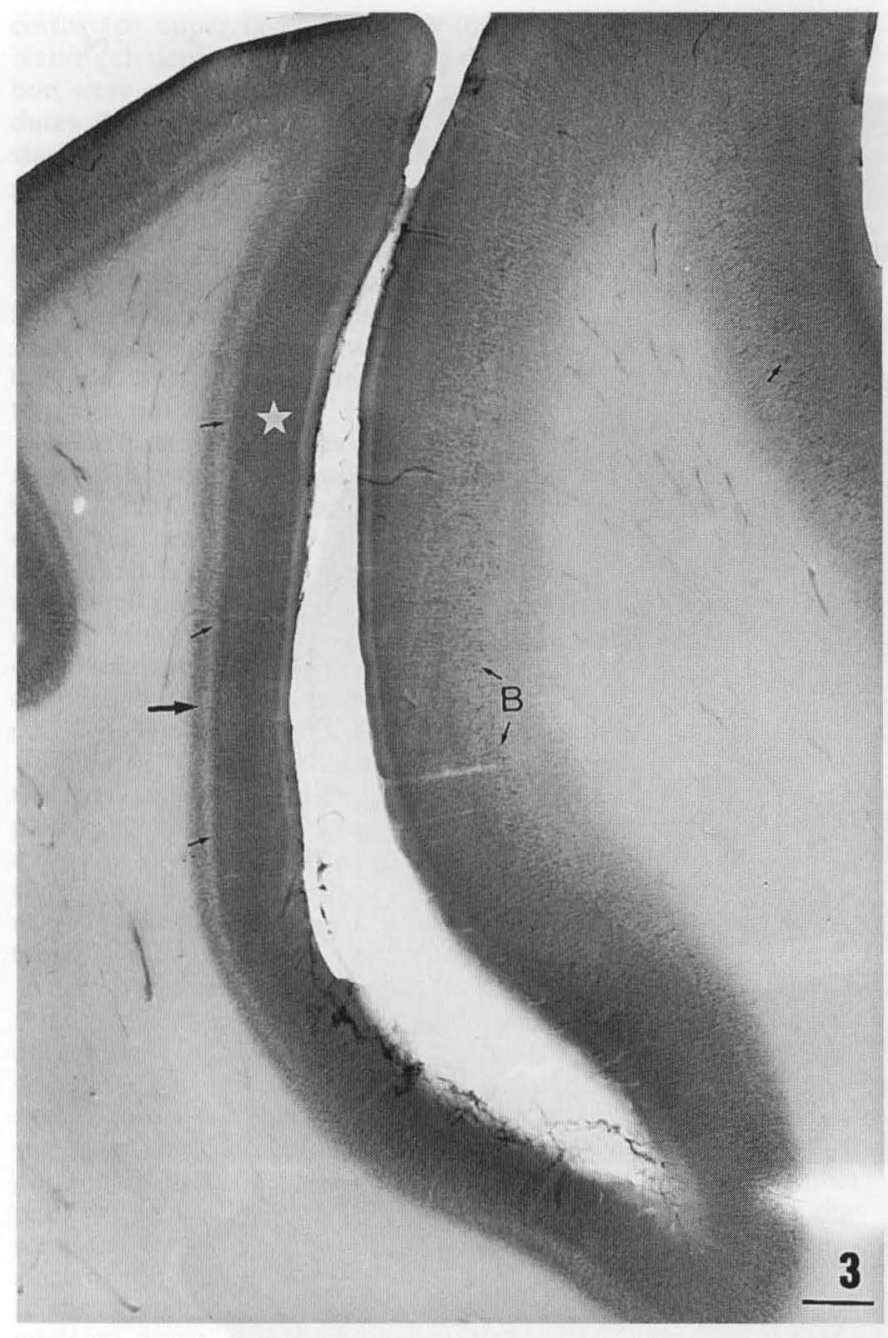

Fig. 3 Pre- (area 4; area FAgamma of Economo and Koskinas [33]) and postcentral gyrus (area 3, 1, 2; areas PB, PC, PD of Economo and Koskinas) of a 36-year-old male control case. The postcentral region is characterized by a thin, heterotypical cortex, high cell density in the supragranular layers (white star), a small and pale layer V (thin arrows), and a thin, cell-rich and welldemarcated layer VI (thick arrows). The cortex of area 4 is slightly obliquely cut, individual Betz cells ( $B$ with arrows, and thin arrow upper right margin) can be recognized at this magnification. Bar $=1 \mathrm{~mm}$

that forced him to resign from his job. Memory disturbances were noticed in the oldest of our cases, whereas the symptoms of the 36-year-old female had originally been diagnosed as schizophrenic.

\section{Routine neuropathology}

Arteriosclerotic changes were absent from larger penetrating and subcortical arteries in the control and Huntington's disease cases. Some penetrating arteries within the ventral putamen and the rostral globus pallidus externus exhibited increased basophilia of their muscular layer in gallocyanin-stained sections. These pheno-

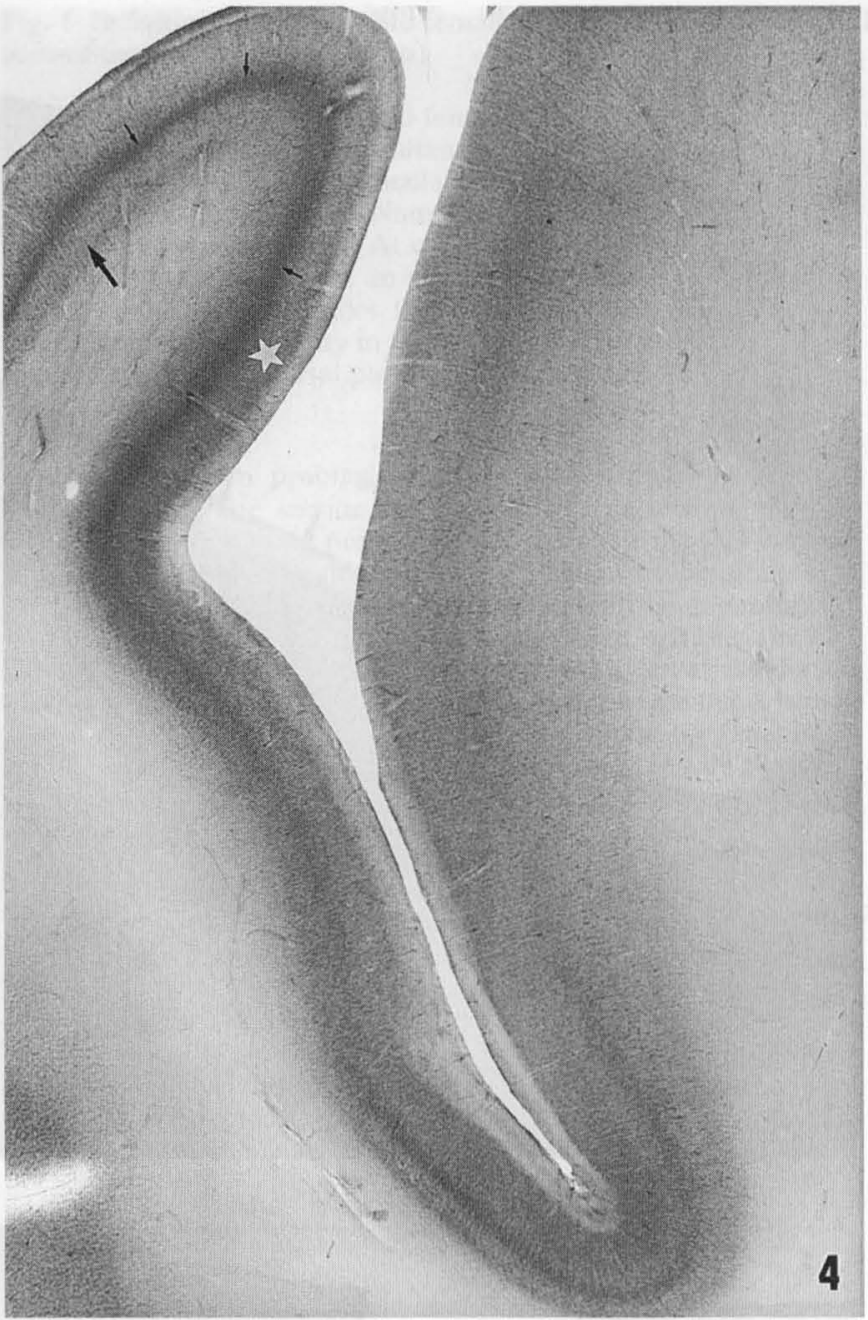

Fig. 4 Pre- (area 4; area FAgamma [33]) and postcentral gyrus (area 3, 1, 2; areas PB, PC, PD [33]) of a 40-year-old male Huntington's patient. Pallor of the supragranular layers in the postcentral gyrus (white star), attenuation of layer VI (thick arrow), conspicuous layer IV (thin arrows). The width of area 4 appears not to be reduced, Betz cells are not visible by technical reasons due to their reduced basophilia but their density is unchanged. Same scale as Fig. 3

mena were observed in both Huntington's disease and control cases. Excessive fibrosis of cerebral arterioles was not encountered either in the 72-year-old male Huntington's or in the 75-year-old control case. Alzheimer's neurofibrillary tangles, senile or amyloid plaques were not present either in the controls or in the cases with Huntington's disease. The coded sections through the basal ganglia from Huntington's disease could be unequivocally diagnosed by a marked increase of fibrous astrocytes in Gallyas-stained sections and by a considerably decreased density of small striatal neurones (Figs. 1, 2). 

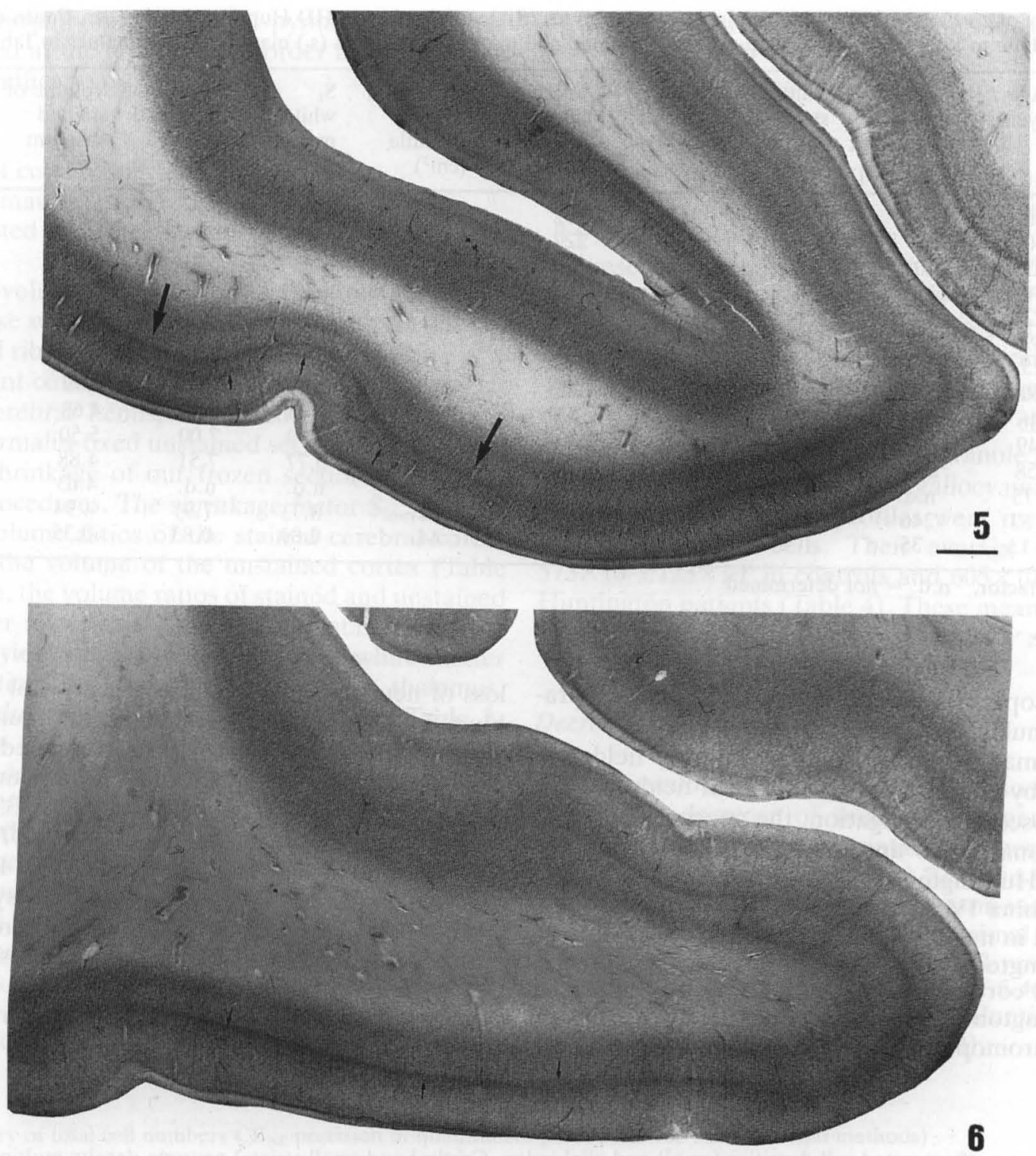

Fig. 5 Inferior temporal gyrus covered by Brodmann's area 20 (TE2 in [33]) of a 36-year-old male control case. This field is classified frontal type 2 by its lamination [33]. The cortex is wide and pyramidal cells predominate, especially in layer V (thick arrows). Although Economo and Koskinas [33] did not mention a welldeveloped layer IIIc in their monograph, isolated large IIIc pyramidal neurones are described in the English translation [32]. These cells form a clear-cut row in thick gallocyanin-stained sections (thin arrows) separated by a cell-poor cleft from layer IV. Bar $=1 \mathrm{~mm}$

Laminar pathology in thick frozen gallocyanin-stained sections

Cytoarchitectonically, primary sensory fields are characterized by thin, cell-rich cortical ribbons. The term koniocortex is used to express granularisation of neurones in layers II to IV. Layer Vb is cell sparse and layer VI thin and well demarcated (Fig. 3). These primary sensory fields comprising Brodmann's areae 3, 1, 2, 41,
Fig. 6 Inferior temporal gyrus covered by Brodmann's area 20 (TE2 in [33]) of a 40-year-old male patient with Huntington's disease. The overall width of area 20 is higher in the Huntington's patient. The brain of the control case (Fig. 5) was subdivided by numerous tertiary gyri. In our experience, heavy brains are frequently well gyrated and are covered by a thin expanded cortex, whereas in less-well gyrated brains the cortices are thicker. Furthermore, the cortical shrinkage factor was 0.53 in the control case and 0.49 in the patient with Huntington's disease (Table 2). These fundamental differences in gross anatomy in association with technical factors render assessment of cortical thickness difficult. The row of layer IIIc pyramidal cells is absent and layer IV together with superficial layer $\mathrm{V}$ pyramidal cells (thin arrows) is prominent in temporal association fields of Huntington's disease patients. Both corrected cortical volumes were nearly identical (Table 2)

and 17 were heavily afflicted by conspicuous nerve cell loss in layers III and VI (Fig. 4). Only few, unusually large pyramidal cells were spared in layer III of the primary sensory fields. Neurones in layers IV and Va appeared resistant to cell degeneration and these layers 
Table 2 Summary of cortical and subcortical volumes and $\mathrm{s}_{\mathrm{f}}$ values $\left(\mathbf{S}_{\mathrm{f}}\right.$ shrinkage factor, HD Huntington's disease, Contr. control, $\mathbf{n} . \mathbf{d}$. not determined. Due to rounding errors the quotients of stained and unstained volumes $\left(\mathrm{s}_{\mathrm{f}}\right)$ may differ from values in Table 2.)

\begin{tabular}{|c|c|c|c|c|c|c|c|c|c|c|}
\hline $\begin{array}{l}\text { Diagnosis } \\
\text { and sex }\end{array}$ & $\begin{array}{l}\text { Age } \\
\text { (years) }\end{array}$ & $\begin{array}{l}\text { Volume of } \\
\text { unstained } \\
\text { left cortex } \\
\left(\mathrm{cm}^{3}\right)\end{array}$ & $\begin{array}{l}\text { Volume of } \\
\text { stained left } \\
\text { cortex } \\
\left(\mathrm{cm}^{3}\right)\end{array}$ & $\begin{array}{l}\mathrm{S}_{\mathrm{f}} \\
\text { cortex }\end{array}$ & $\begin{array}{l}\text { Volume of } \\
\text { unstained } \\
\text { medulla } \\
\left(\mathrm{cm}^{3}\right)\end{array}$ & $\begin{array}{l}\text { Volume of } \\
\text { stained } \\
\text { medulla } \\
\left(\mathrm{cm}^{3}\right)\end{array}$ & $\begin{array}{l}\mathrm{S}_{\mathrm{f}} \\
\text { white } \\
\text { matter }\end{array}$ & $\begin{array}{l}\text { Volume of } \\
\text { unstained } \\
\text { striatum } \\
\left(\mathrm{cm}^{3}\right)\end{array}$ & $\begin{array}{l}\text { Volume of } \\
\text { stained } \\
\text { striatum } \\
\left(\mathrm{cm}^{3}\right)\end{array}$ & $\begin{array}{l}\mathrm{S}_{\mathrm{f}} \\
\text { striatum }\end{array}$ \\
\hline HD female & 36 & 160 & 93 & 0.58 & 132 & 90 & 0.68 & 4.13 & 1.71 & 0.41 \\
\hline HD male & 40 & 262 & 127 & 0.49 & 227 & 170 & 0.75 & 3.91 & 2.41 & 0.62 \\
\hline HD male & 41 & 160 & 103 & 0.64 & 122 & 108 & 0.88 & 3.30 & 2.16 & 0.66 \\
\hline HD female & 54 & 212 & 108 & 0.51 & 148 & 135 & 0.91 & 3.59 & 2.28 & 0.63 \\
\hline SD & 15 & 43 & 12 & 0.07 & 42 & 32 & 0.11 & 0.52 & 0.42 & 0.10 \\
\hline Contr. male & 36 & 265 & 141 & 0.53 & 253 & 192 & 0.76 & 8.90 & 4.99 & 0.56 \\
\hline Contr. female & 46 & 202 & 135 & 0.67 & 229 & 138 & 0.60 & 8.22 & 4.68 & 0.57 \\
\hline Contr. male & 49 & 281 & 150 & 0.53 & 304 & 241 & 0.79 & 7.00 & 5.50 & 0.79 \\
\hline Contr. female & 58 & 236 & 129 & 0.55 & 212 & 164 & 0.77 & 7.51 & 4.88 & 0.65 \\
\hline Contr. male & 75 & n.d. & 133 & n.d. & n.d. & n.d. & n.d. & n.d. & 4.63 & n.d. \\
\hline
\end{tabular}

$\mathrm{S}_{\mathrm{f}}=$ shrinkage factor, n.d. $=$ not determined

formed a basophilic cell band separating the pale supraand infragranular layers.

In the human neocortex, primary sensory fields are surrounded by an excess of associational fields. At low power microscope investigation, the neocortical ribbon of associational fields appeared remarkably well preserved in Huntington's disease cases. The border between lamina IV and superficial lamina $V$ was more pronounced in most fields of the cortical lobes of cases with Huntington's disease than in matched controls. The overall cortical thickness was reduced in all cases with Huntington's disease, and the supragranular layer was less chromophilic due to a slight to intermediate loss of neurones. An increase of astroglial cells, which blurs in our experience the laminar boundaries in a highly characteristic manner, was not noted. After careful examination of the temporal (Brodmann's [18] areas 20 and 21; von Economo and Koskinas' [33] fields TE2 and TE1) and parietal (Brodmann's areas 7, 40, and 39; von Economo and Koskinas' fields PE, PF, and PG) neocortex a nearly complete absence of layer IIIc pyramids was noted (Figs. 5,6). The assessment of IIIc neuronal depletion was difficult to accomplish due to the irregular convolution of the respective hemispheric gyri, interareal differences and probable interindividual differences. In most cortical fields, a few, widely

Table 3 Summary of corrected cell densities $\left(\mathrm{cm}^{-3}\right)$ and glial index. Cortical and small striatal neurone density multiplied by volumes of stained cortex and striatum, respectively (Table 2), yields total neurone numbers in cortex and striatum. Due to rounding errors these products differ from data given in Table 3 (n.d. not determined).

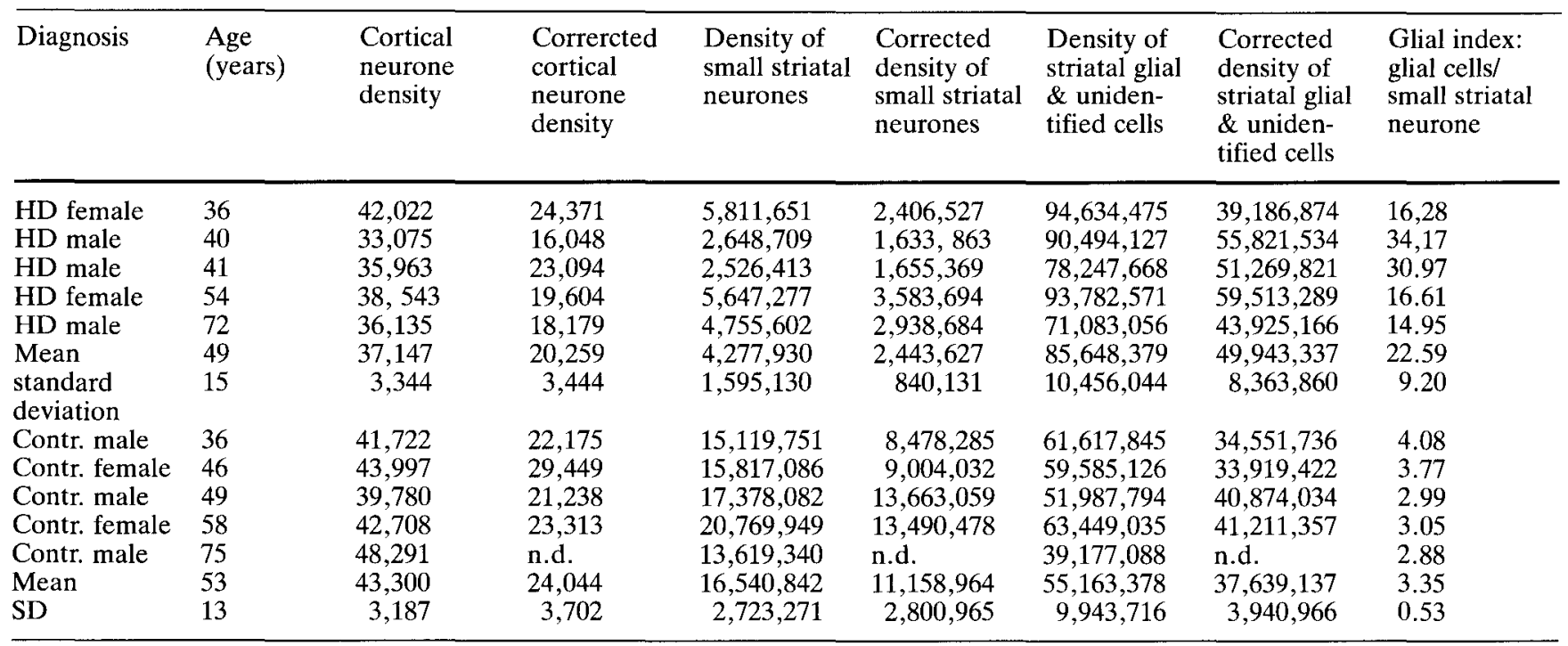


spaced, unusually large layer III pyramidal cells could be observed at the layer III/IV border at higher microscope magnification.

Volumes of cortex, subcortical nuclei and white matter, uncorrected

and corrected cell densities and glial index

The mean volume of the stained left cortex in Huntington's disease was by $26.7 \%$ lower than the corresponding cortical ribbon in the five control case (Table $2, P \leq$ 0.012 ). Point counting in gallocyanin-stained serial sections of cerebral hemispheres and point counting in parallel, formalin-fixed unstained sections provide data on tissue shrinkage of our frozen sections during histological procedures. The shrinkage factor $S_{\text {fcortex }}$ represents the volume ratios of the stained cerebral cortex divided by the volume of the unstained cortex (Table 2). Likewise, the volume ratios of stained and unstained white matter as well as stained and unstained subcortical nuclei yield shrinkage factors of the white matter and subcortical nuclei including striatum, thalamus, globus pallidus, and amygdala, respectively (Table 2, $\left.\mathrm{S}_{\mathrm{fwhitte} \mathrm{matter}}, \mathrm{s}_{\mathrm{fstriatum}}\right)$. The shrinkage factors of white matter differed considerably from that of the cortex, the means of the cortical and striatal shrinkage factors differed by less than $10 \%$, but individual shrinkage factors may also diverge considerably. Multiplication of neurone densities by shrinkage factors of the containing space (cortex, striatum) yields corrected cell densities (Table 3). The glial index is the quotient from striatal glial densities and striatal neurone densities (Table 3 ). It was 3.35 in controls and nearly seven times higher in Huntington's disease (Table 3).
Total nerve cell number in Huntington's disease

\section{Reduced cortical neurone number in Huntington's disease}

The mean total nerve cell number in the left cerebral cortex of Huntington's disease patients was $3.99 \times 10^{9} \pm 218 \times 10^{6}$ neurones (Table 4). This number represents a mean $33 \%$ deficit compared with the ageand sex-matched controls, where the left cerebral cortex contained an average of $5.97 \times 10^{9} \pm 321 \times 10^{6}$ neurones. The total nerve cell number in control cases was invariably higher than in cases with Huntington's disease patients (Mann-Whitney U-Test, $P \leq 0.012$ ).

The distinction between small granule and astroglial cells was not always possible in gallocyanin-stained section. Equivocal nuclear profiles were recorded as unidentified cortical cells. Their average number was $573 \times 10^{6} \pm 123 \times 10^{6}$ in controls and $605 \times 10^{6} \pm 95 \times 10^{6}$ in Huntington patients (Table 4 ). These means did not differ significantly (Mann-Whitney U-test $P \leq 0.53$ ).

\section{Decreased striatal nerve cell number}

The conspicuous striatal atrophy was associated with a tremendous decrease of small striatal neurones. The average number of small striatal neurones in controls was $82 \times 10^{6} \pm 15.8 \times 10^{6}$ versus $9.72 \times 10^{6} \pm 3.64 \times 10^{6}$ in Huntington's disease cases. An enormous individual variability could be observed. A maximal number of $13.65 \times 10^{6}$ striatal cells was found in a 72 -year-old Huntington patient and a minimal number of $5.46 \times 10^{6}$ striatal neurones in 41-year-old male with Huntington's disease (Mann-Whitney U-test $P \leq 0.012$ ).

Table 4 Summary of total cell numbers $\mathbf{C E}_{\mathrm{NE}}$ precision of quantitative procedure: see Materials and methods)

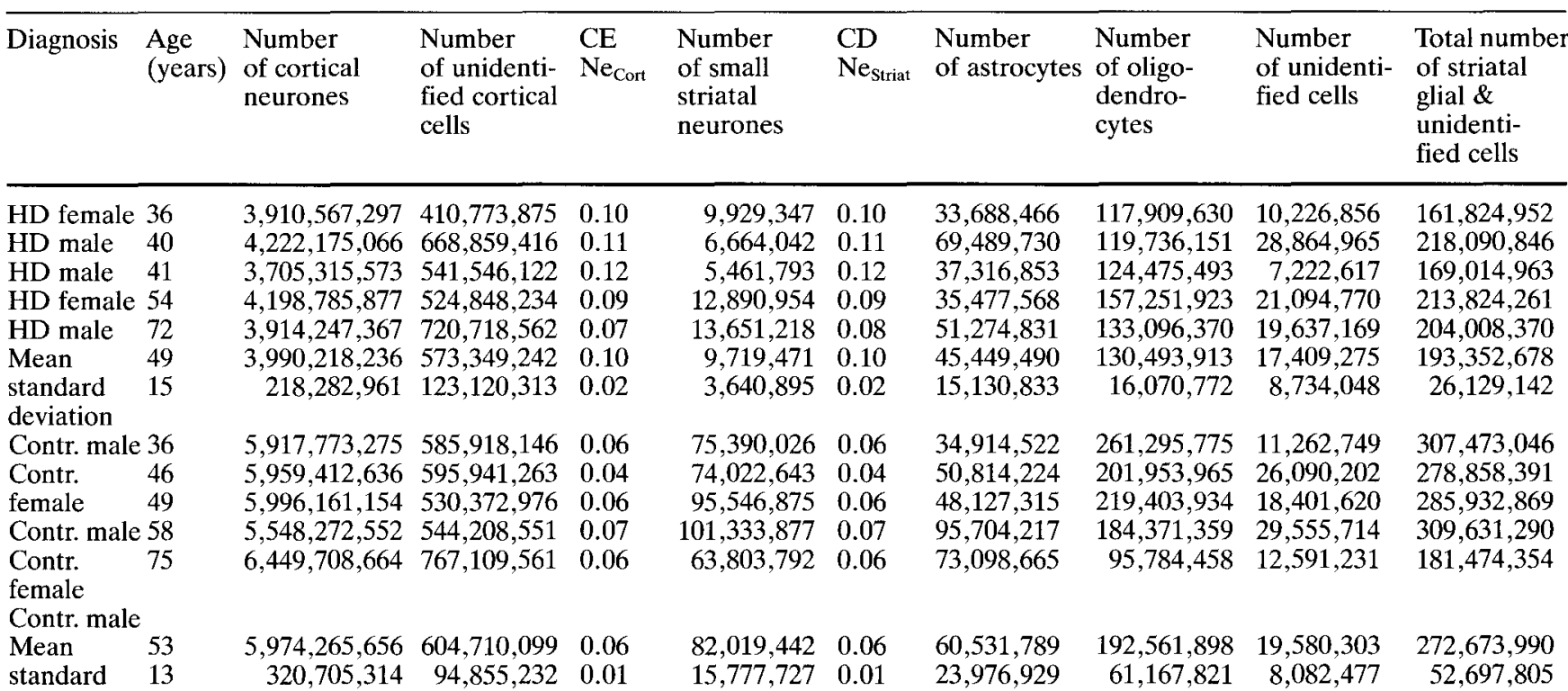

deviation 


\section{Correlation of total cortical} with total striatal neurone number

In our control sample of five cases, striatal neuronal number $(\mathrm{Y})$ correlated negatively with the total cortical neurone number $(\mathrm{X})$. This statistically non-significant correlation was expressed by the equation

$\mathrm{Y}=-3.9131124 \times 10^{-2} \times \mathrm{X}+315.79 \times 10^{6}$

with Spearman' rank correlation coefficient $\varrho=-0.700$, $P \leq 0.19$.

In the five cases with Huntington's disease, striatal number $(\mathrm{X})$ correlated positively with total cortical neurone number $(\mathrm{Y})$, although statistically less significant $(\varrho=0.300, P \leq 0.62)$ by the equation $\mathrm{Y}=4.4616754 \times 10^{-3} \times \mathrm{X}-8.083 \times 10^{6}$.

\section{Neuroglia}

The mean number of astrocytes, oligodendrocytes, and unidentified glial cells was higher in the control cases (Table 4). In Huntington's disease, the majority of astroglial nuclei were considerably enlarged and the astroglial perikaryon contained numerous fine lipofuscin granules. Astroglial cells could well be distinguished from oligodendrocytes in Huntington's disease, whereas in the controls the distinction was based mainly on size differences and remained arbitrary.

\section{Discussion}

\section{Methodological considerations}

Our quantitative results of reduced cortical nerve cell number in Huntington's disease patients substantiate qualitative observations $[5,19,20,40,46,80,83,99$, $116]$ and extend previous quantitative investigations on cortical atrophy $[28,74,75,79]$ and reduced nerve cell density $[25,53,108,110]$.

The overall $33 \%$ decrease in total neurone number results from a combined decrease of cortical volume and decreased neurone density (Tables 2 and 3 ). Cortex, subcortical nuclei, and white matter of individual brains are prone to considerably divergent shrinkage factors (Table 2). Therefore, neurone or glial densities (or reconstruction of cell size) must always be corrected with individual as well as tissue-specific shrinkage factors to obtain fresh volumes that reproduce cell densities or cell sizes in unfixed (in vivo) tissue [69]. By calculating total cell number these factors are eliminated. To our knowledge, the present data together with a preliminary report [56] are the first estimations of total neuronal cortical number in Huntington's disease patients. Total nerve cell number in both hemispheres was estimated to range from $10 \times 10^{9}-15 \times 10^{9}$ neurones [49-51]. These results are in agreement with our estimations of an average of $5.97 \times 10^{9}$ neurones in one hemisphere but our and Haug's data are only half the num- ber given by other authors [16,89-91]. This is difficult to explain since our stereological procedures were nearly identical to those applied by Braendgaard et al. [16]. One explanation could be the classification of cellular profiles in gallocyanin-stained preparations. Sometimes, we found it difficult to distinguish astroglial nuclei from small neocortical layer II and layer IV granule cells. Equivocal profiles were quantified as unidentified cell types in Table 4 . This uncertainty was the main reason for abandoning glial counting in the cerebral cortex. Braendgaard et al. [16] used the Giemsa stain in their investigation. This mixture could probably stain perikarya that were only weakly or not at all stained by gallocyanin. At variance with our protocol, Braendgaard et al. [16] estimated the volume of the human prosencephalon in unstained 5-mm-thick frozen sections. The nerve cell density was estimated after embedding small cortical wedges in glycol methacrylate. Braendgaard et al. [16] observed up to $15 \%$ tissue shrinkage after glycol methacrylate embedding, but they did not correct the nerve cell density estimations. Finally, Braendgaard et al. [16] removed the medullary layer prior to glycol methacrylate processing. Layer VIb is known to have uncertain boundaries with the underlying medullary layer outside primary sensory fields. Exclusion of deep layer VI with its very low neuronal density could introduce a bias in average nerve cell density estimations and result in overestimation of total nerve cell number. On the other hand, our uncorrected nerve cell densities (Table 3) are nearly identical to those of Braendgaard et al. [16].

According to Schröder et al. [107] the total number of small striatal neurones is $110 \times 10^{6}$ in males and $105 \times 10^{6}$ in females. These data were derived from a total of 13 individuals, 9 males and 4 females, ranging in age from 19 to 99 years. In a subsequent study, Lange et al. [74] reported $97.8 \times 10^{6}$ microneurones in the striatum of 6 males and $98.7 \times 10^{6}$ neurones in the striatum of 8 females. In 5 cases of Huntington's disease, Lange et al. [74] observed a $92.4 \%$ decrease of microneurones to an average of $7.42 \times 10^{6}$. The total number of small striatal cells in these previous investigations is about $20 \%$ higher than in our control cases and $24 \%$ less than in our Huntington's diseases subjects. This difference is most likely due to different approaches in counting and sampling as well as individual differences in striatal neurone number (see also Table 3). Schröder et al. [107] recorded the nucleolar number of small striatal neurones at 375-fold microscopic magnification. In our experience, even using an oil-immersion objective, heterochromatin granules can be confused with nucleolar profiles. In addition, nerve cell density was exclusively estimated by Schröder et al. [107] in intermediate parts of the putamen, whereas we were meandering through all parts of the striatum, the caudate nucleus as well as the ventral striatum and nucleus accumbens (Fig. 1).

Lange [75] calculated a total striatal glia number of $422.5 \times 10^{6}$ cells in six females and eight males. This 
mean number is considerably higher than our estimation $\left(272.7 \times 10^{6}\right.$ cells, including unidentified cells, Table 4). The same holds true for total glia number in Huntington's disease. We found $193 \times 10^{6}$ glial together with unidentified cells in the striatum of Huntington's disease patients (Table 4), Lange [75] reported $363 \times 10^{6}$ glial cells in five Huntington patients. Lange [75] did not mention correction procedures that have a great impact on nuclear instead of nucleolar profile counting in 20- $\mu \mathrm{m}$-thick paraffin sections. Nevertheless, our data confirm the observation of Lange et al. [74] of a reduced total astroglia number in Huntington's disease despite the drastically increased glial density in the visual field. The glial index, the ratio of glial cells per neurone, is nearly identical to the number reported by Schröder et al. [107]. This ratio increased markedly to 22.6 glial cells per neurone in Huntington's disease (Table 3).

\section{Laminar and areal versus diffuse nerve cell loss}

The total nerve cell number was investigated in five terminal cases of Huntington's disease. The average deficit in neurone number of $33 \%$ observed in our Huntington's disease patients (Table 4 ) is a consequence of a long-lasting process afflicting cortical as well as subcortical structures. Nevertheless, neuronal degeneration was not uniformly distributed over the cerebral cortex and its laminae. Primary sensory areas including Brodmann's areae 3,1,2 (Fig. 4), area 17, and area 41 exhibited a conspicuous neuronal depletion of the supragranular layers. This contrasts with subtle changes in the temporal association fields comprising areas 20, 21 (Fig. 6 ), and parietal association fields. In our preparations, these fields were characterized by the nearly complete disappearance of IIIc pyramidal neurones with a few widely dispersed large pyramidal cells spared. Neuronal loss in prefrontal and premotor fields appeared intermediate between primary sensory and parietal as well as temporal fields. Thus, our results are congruent with reports of an overall reduced nerve cell density [108], selective loss of pyramidal neurones containing a nonphosphorylated neurofilament reactive to a monoclonal (SMI-32) antibody [25], reduced nerve cell density in layers V and VI [108, 109], and probable hypertrophy of a subset of pyramidal neurones [109]. One conspicuous feature in low-power microscopic inspection of serial frontal sections was a clearly demarcated layer IV in isocortical fields. This phenomenon, which is rather diagnostic in our experience, has been interpreted differently. Vogt and Vogt [119] regarded the pronounced layer IV to be due to laminar accumulation of astroglia cells. In citing Kölpin (1912), Brodmann [18] suspected disturbed neocortical development (Vitium primae formationis) in Huntington's disease. We think this phenomenon is due to the degeneration of layer Va pyramidal cells and a subsequent closer spacing of layer IV granule cells. A recent quantitative investigation failed to demonstrate conspicuous astroglial proliferation in the prefrontal cortex of Huntington's disease patients [108]. Our results are in agreement with the neurochemical investigations of Ellison et al. [35], who found reduced glutamate but unchanged GABA concentrations in the frontal, parietal, and occipital lobes.

Almost all smooth nonpyramidal cells (neurones with short axons and sparsely spiny dendrites) are GABA-ergic [29] and perhaps these spared cells render layer IV/V more distinct in Huntington's disease (Figs. $4,6)$. Reynolds and Pearson [97], on the other hand, reported decreased glutamate as well as GABA concentrations in the temporal lobe of Huntington's disease patients. Differences in the topography as well as differences in clinical staging could contribute to these discrepancies.

\section{Pathoarchitectonics and functional considerations}

The psychiatric and neurological pictures of Huntington's disease have mainly been explained by neuronal depletion in the striatum and affliction of cortico-basal ganglia-cortical circuits $[22,26,39,48,81,82,112,128]$. Decreased laminar as well as area-specific neurone number represent additional factors to be considered in the pathophysiology of Huntington's disease. Selective loss of layer III, V, and VI pyramidal neurones may be due to retrograde degeneration after death of small spiny striatal neurones that are the major targets of cortical projection cells $[6,37,43,65,66,84,88]$. These retrograde phenomena could explain nerve cell loss in frontal, parietal, occipital, and temporal association cortices. At variance with previous conclusions that favoured a restricted topographical pattern of corticostriatal projections [68], recent investigations demonstrated a widespread longitudinal termination of frontal, parietal, occipital, and temporal lobe pyramidal neurone efferents in the caudate nucleus $[36,42,43,65,72$, $78,94,103,111,118,127]$. On the other hand, the primary visual area of monkeys has few, if any, direct connections with the caudate nucleus and ventral putamen [103]. Furthermore, the projection of primary sensory areas to the caudate nucleus are faint in monkeys [73]. It is generally agreed that the caudate nucleus is primarily afflicted in Huntington's disease. These observations favour additional mechanisms of cortical neuronal death besides retrograde degeneration. In addition, electrophysiological observations in early stages of Huntington's disease suggest an early affliction of primary somatosensory fields $[1,34,62,87,117]$. Josiassen et al. [67] described visual as well as auditory deficits in asymptomatic offsprings of Huntington's disease patients. These stages exhibit slight or absent striatal degeneration in post-mortem [86] and NMR studies [44]. Therefore, we interpret the marked laminar nerve cell loss in areas $1-3,17$, and 41 as terminal stages of an early-onset cortical neuronal degeneration.

Neuronal depletion has been reported in other neu- 
ropsychiatric diseases including Alzheimer's and Pick's disease. In the latter, marked striatal degeneration has frequently been described [77]. At variance with Huntington's disease, Pick's disease is characterized by progressive neuronal degeneration from layer II to III to $\mathrm{V}$ in the frontal and temporal lobes [24, 61, 64, 106], whereas Lange [75] pointed to a marked atrophy of parietal and occipital lobes in Huntington's disease. Layer III and layer V of temporal areas 21 and 22 are prone to synapse loss in Alzheimer's disease [105] and a subset of pyramidal cells in layers III and V appears to be afflicted by senile processes and preferentially lost in this disease and in HIV encephalopathy [7, 14, 23, 27, $52,59,60,76,125]$. Taken together, these observations show laminar and areal similarities as well as differences of nerve cell degeneration in Huntington's, Pick's and Alzheimer's disease, and in virus-induced dementia.

Nevertheless, a coherent morphological explanation of clinical phenomena in these major neurodegenerative diseases is presently not possible. Diffuse cortical nerve cell loss is insufficient to explain dementia. In a preliminary study [56] we found $4.4 \times 10^{9}$ cortical neurones with considerable astrogliosis in a non-demented 72-year-old male. The cortex in this case contained only about $10^{8}$ neurones more than the least affected cortex in a 54-year-old female patient with Huntington's disease (Table 4). Senile and amyloid plaques were absent in this 72-year-old male. Reinvestigation of the clinical records revealed that the patient had suffered from severe arteriosclerosis and had both thighs amputated.

In Huntington's disease, besides the involvement of subcortical grisea, allocortical regions are invariably affected in the course of the illness. Interestingly, the laminar pathology of the entorhinal region in Huntington's disease differs markedly from Alzheimer's disease. The pre-alpha layer exhibits massive neurofibrillary tangles in Alzheimer's disease [8, 11, 47, 63, 93, 100], whereas the pre-beta and pri-layers are attenuated in Huntington's disease $[12,13,57]$. The latter laminae are known to connect hippocampal with neocortical fields [126]. Neuropsychological tests have been claimed to distinguish memory deficits found in Huntington's disease from those seen in Alzheimer's disease [17, 21, 92, 104].

In conclusion, sub-, neo- and allocortical regional and laminar neuronal degeneration in Huntington's disease represents a challenge towards a combined clinicalmorphological approach in unravelling the pathophysiology of this disease and the function of the human $\mathrm{CNS}$ in general.

Acknowledgements The technical assistance of Mrs. E. Broschk and E. Gößmann, the photographic assistance of Mr. W. Nisch, the secretarial and linguistic help of Mrs. R. Huttner, and the statistical advice of Dr. I. Haubiz are gratefully acknowledged.

\section{References}

1. Abbruzzese G, Dall'Agata D, Morena M, Reni L, Favale E (1990) Abnormalities of parietal and prerolandic somatosensory evoked potentials in Huntington's disease. Electroencephalogr Clin Neurophysiol 77: 340-346

2. Albin RL, Young AB, Penney JB (1989) The functional anatomy of basal ganglia disorders. Trends Neurosci 12: 366-375

3. Alexander GE, DeLong MR, Strick PL (1986) Parallel organization of functionally segregated circuits linking basal ganglia and cortex. Annu Rev Neurosci 9: 357-381

4. Alexander GE, Crutcher MD, DeLong MR (1990) Basal ganglia-thalamocortical circuits: parallel substrates for motor, oculomotor, "prefrontal" and "limbic" functions. Prog Brain Res 85: 119-146

5. Alzheimer A (1911) Über die anatomische Grundlage der Huntingtonschen Chorea und der choreatischen Bewegungen überhaupt. Neurol Centralbl 30: 891-892

6. Arikuni T, Kubota K (1986) The organization of prefrontocaudate projections and their laminar origin in the macaque monkey: a retrograde study using HRP-gel. J Comp Neurol 244: $492-510$

7. Armstrong RA (1993) Is the clustering of neurofibrillary tangles in Alzheimer's patients related to the cells of origin of specific cortico-cortical projections. Neurosci Lett 160: 57-60

8. Bancher C, Braak H, Fischer P, Jellinger KA (1993) Neuropathological staging of Alzheimer lesions and intellectual status in Alzheimer's and Parkinson's disease patients. Neurosci Lett 162: 179-182

9. Bauchot R (1967) Les modifications du poid encéphalique au cours de la fixation. J Hirnforsch 6: 253-283

10. Braak H (1980) Architectonics of the human telencephalic cortex. In: Braitenberg V (ed) Studies on brain function. Springer, Berlin Heidelberg New York, pp 1-147

11. Braak H, Braak E (1991) Neuropathological stageing of Alzheimer-related changes. Acta Neuropathol 82: 239-259

12. Braak H, Braak E (1992) Allocortical involvement in Huntington's disease. Neuropathol Appl Neurobiol 18: 539-547

13. Braak H, Braak E (1992) Layer-specific allocortical destruction in Huntington's chorea (abstract). Clin Neuropathol 11: 278

14. Braak H, Braak E, Kalus P (1989) Alzheimer's disease: areal and laminar pathology in the occipital isocortex. Acta Neuropathol 77: 494-506

15. Braendgaard H, Gundersen HJG (1986) The impact of recent stereological advances on quantitative studies of the nervous system. J Neurosci Methods 18: 39-78

16. Braendgaard H, Evans SM, Howard CV, Gundersen HJ (1990) The total number of neurons in the human neocortex unbiasedly estimated using optical disectors. J Microsc 157: 285-304

17. Brandt J, Folstein SE, Folstein MF (1988) Differential cognitive impairment in Alzheimer's disease and Huntington's disease. Ann Neurol 23: 555-561

18. Brodmann K (1909) Vergleichende Lokalisationslehre der Großhirnrinde. J.A. Barth, Leipzig

19. Bruyn GW (1968) Huntington's chorea. Historical, clinical and laboratory synopsis. Handb Clin Neurol 6: 298-378

20. Bruyn GW, Bots GTAM, Dom R (1979) Huntington's chorea: current neuropathological status. Adv Neurol 23: 83-93

21. Butters N, Albert MS, Sax D (1979) Investigations of the memory disorders of patients with Huntington's disease. Adv Neurol 23: 203-213

22. Caine ED, Hunt RD, Weingartner H, Ebert MH (1978) Huntington's dementia. Clinical and neuropsychological features. Arch Gen Psychiatry 35: 377-384

23. Catalá I, Ferrer I, Galofré E, Fábregues I (1988) Decreased numbers of dendritic spines on cortical pyramidal neurons in dementia. A quantitative Golgi study on biopsy samples. Hum Neurobiol 6: 255-259 
24. Constantinidis J, Richard J, Tissot R (1974) Pick's disease: histological and clinical correlations. Eur Neurol 11: 208-217

25. Cudkowicz M, Kowall NW (1990) Degeneration of pyramidal projection neurons in Huntington's disease cortex. Ann Neurol 27: 200-204

26. Cummings JL (1993) Frontal-subcortical circuits and human behavior. Arch Neurol 50: 873-880

27. Davies CA, Mann DMA, Sumpter PQ, Yates PO (1987) A quantitative morphometric analysis of the neuronal and synaptic content of the frontal and temporal cortex in patients with Alzheimer's disease. J Neurol Sci 78: 151-164

28. de la Monte SM, Vonsattel JP, Richardson EP Jr (1988) Morphometric demonstration of atrophic changes in the cerebral cortex, white matter, and neostriatum in Huntington's disease. J Neuropathol Exp Neurol 47: 516-525

29. DeFelipe J (1993) Neocortical neuronal diversity: chemical heterogeneity revealed by colocalization studies of classic neurotransmitters, neuropeptides, calcium-binding proteins, and cell surface molecules. Cerebral Cortex 3: 273-289

30. Drüge H, Heinsen H, Heinsen YL (1986) Quantitative studies in ageing Chbb:THOM(Wistar) rats. II. Neuron numbers in lobules I, VIb $+\mathrm{c}$ and X. Bibl Anat 28: 121-137

31. Dunlap CB (1927) Pathologic changes in Huntington's chorea: with special reference to the corpus striatum. Arch Neurol Psychiatry 18: 867-943

32. Economo C v (1929) The cytoarchitectonics of the human cerebral cortex. Oxford University Press, London, pp 1-186

33. Economo C v, Koskinas GN (1925) Die Cytoarchitektonik der Hirnrinde des erwachsenen Menschen. Julius Springer, Wien Berlin, pp 1-810

34. Ehle AL, Stewart RM, Lellelid NA, Leventhal NA (1984) Evoked potentials in Huntington's disease. A comparative and longitudinal study. Arch Neurol 41: 379-382

35. Ellison DW, Beal MF, Mazurek MF, Malloy JR, Bird ED, Martin JB (1987) Amino acid neurotransmitter abnormalities in Huntington's disease and the quinolinic acid animal model of Huntington's disease. Brain 110: 1657-1673

36. Faull RL, Nauta WJ, Domesick VB (1986) The visual corticostriato-nigral pathway in the rat. Neuroscience 19: 1119-1132

37. Fisher RS, Boylan MK, Hull CD, Buchwald NA, Levine MS (1986) Branched projections of cat sensorimotor cortex: multiple retrograde labeling via commissural corticocortical, decussated corticostriatal and undecussated corticostriatal axons. Brain Res 384: 395-400

38. Flood DG, Coleman PD (1987) Neuron numbers and sizes in aging brain: comparison of human, monkey, and rodent data. Neurobiol Aging 9: 453-463

39. Folstein SE (1989) Huntington's disease: a disorder of families. Johns Hopkins University, Baltimore

40. Forno LS, Jose C (1973) Huntington's chorea: a pathological study. In: Barbeau A, Chase TN, Paulson GW (eds) Huntington's chorea 1872-1972. Huntington's chorea, vol 1. Raven Press, New York, pp 453-470

41. Gallyas F (1981) An argyrophil III method for the demonstration of fibrous neuroglia. Acta Morphol Acad Sci Hung 29: 185-193

42. Goldman PS, Nauta WJ (1977) An intricately patterned prefronto-caudate projection in the rhesus monkey. J Comp Neurol 72: 369-386

43. Goldman-Rakic PS, Selemon LD (1986) Topography of corticostriatal projections in nonhuman primates and implications for functional parcellation of the neostriatum. In: Jones EG, Peters A (eds) Cerebral cortex, vol 5. Plenum Press, New York, pp 447-466

44. Grafton ST, Mazziotta JC, Pahl JJ, St.George Hyslop P, Haines JL, Gusella J, Hoffman JM, Baxter LR, Phelps ME (1990) A comparison of neurological, metabolic, structural, and genetic evaluations in persons at risk for Huntington's disease. Ann Neurol 28: 614-621

45. Gundersen HJ (1986) Stereology of arbitrary particles. A review of unbiased number and size estimators and the presentation of some new ones - In memory of William R. Thompson. J Microsc 143: 3-45
46. Hallervorden J (1957) Huntingtonsche Chorea (Chorea chronica progressiva hereditaria). In: Scholz W (ed) Handbuch der speziellen pathologischen Anatomie und Histologie, vol. XIII. Erkrankungen des zentralen Nervensystems, Teil 1/A. Springer, Berlin Göttingen Heidelberg, pp 793-822

47. Hansen LA, Masliah E, Quijada-Fawcett S, Rexin D (1991) Entorhinal neurofibrillary tangles in Alzheimer disease with Lewy bodies. Neurosci Lett 129: 269-272

48. Hasselbalch SG, Oberg G, Sorensen SA, Andersen AR, Waldemar G, Schmidt JF, Fenger K, Paulson OB (1992) Reduced regional cerebral blood flow in Huntington's disease studied by SPECT. J Neurol Neurosurg Psychiatry 55: $1018-1023$

49. Haug H (1970) Quantitative data in neuroanatomy. Prog Brain Res 33: 113-127

50. Haug $\mathbf{H}$ (1985) Are neurons of the human cerebral cortex really lost during aging? A morphometric examination. In: Traber J, Gispen WH (eds) Senile dementia of the Alzheimer type. Springer-Verlag, Berlin Heidelberg New York Tokyo, pp $150-163$

51. Haug H, Eggers R (1992) Methods and problems in the quantitative study of cerebral cortex. In: Fujisawa K, Morimatsu Y (eds) Development and involution of neurones. Japan Scientific Societies Press, Tokyo, pp 203-217

52. Heckers S, Geula C, Mesulam MM (1992) Acetylcholinesterase-rich pyramidal neurons in Alzheimer's disease. Neurobiol Aging 13: 455-460

53. Hedreen JC, Peyser CE, Folstein SE, Ross CA (1991) Neuronal loss in layers V and VI of cerebral cortex in Huntington's disease. Neurosci Lett 133: 257-261

54. Heinsen H, Heinsen YL (1991) Serial thick, frozen, gallocyanin-stained sections of human central nervous system. J Histotechnol 14: 167-173

55. Heinsen H, Beckmann H, Heinsen YL, Gallyas F, Haas S, Scharff G (1990) Laminar neuropathology in Alzheimer's disease by a modified Gallyas impregnation. Psychiatry Res 29: 463-465

56. Heinsen H, Bauer M, Berger K, Ulmar G (1991) Cortical nerve cell loss in Huntington's disease: a stereological investigation in five cases (abstr). Clin Neuropathol 10: 257

57. Heinsen $H$, Bauer M, Ulmar G, Gangnus D, Jungkunz G (1992) The entorhinal region in Huntington's disease: a cytoarchitectonic and quantitative investigation in five cases (abstract). Clin Neuropathol 11: 226

58. Heinsen H, Henn R, Eisenmenger W, Götz M, Bohl J, Bethke B, Lockemann U, Püschel K (1994) Quantitative investigations on the human entorhinal area: left-right asymmetry and age-related changes. Anat Embryol (in press)

59. Hof PR, Morrison JH (1990) Quantitative analysis of a vulnerable subset of pyramidal neurons in Alzheimer's disease. II. Primary and secondary visual cortex. J Comp Neurol 301: $55-64$

60. Hof PR, Cox K, Morrison JH (1990) Quantitative analysis of a vulnerable subset of pyramidal neurons in Alzheimer's disease. I. Superior frontal and inferior temporal cortex. J Comp Neurol 301: 44-54

61. Hof PR, Bouras C, Perl DP, Morrison JH (1994) Quantitative neuropathologic analysis of Pick's disease cases: cortical distribution of Pick bodies and coexistence with Alzheimer's disease. Acta Neuropathol 87: 115-124

62. Huttunen J, Homberg V, Lange HW (1993) Precentral and postcentral somatosensory evoked potentials in Huntington's disease: effects of stimulus repetition rate. J Neurol Sci 116: $119-124$

63. Hyman BT, van Hoesen GW, Damasio AR (1990) Memoryrelated neural systems in Alzheimer's disease: an anatomic study. Neurology 40: 1721-1730

64. Jakob H (1979) Die Picksche Krankheit. Eine neuropathologisch-anatomisch-klinische Studie. In: Hippius H, Janzarik W, Müller C (eds) Monographien aus dem Gesamtgebiete der Psychiatrie. Psychiatry Series. Springer, Berlin Heidelberg New York, pp 1-110 
65. Jones EG (1984) Laminar distribution of cortical efferent cells. In: Peters A, Jones EG (eds) Cerebral cortex, vol 1. Plenum Press, New York, pp 521-553

66. Jones EG, Coulter JD, Burton H, Porter R (1977) Cells of origin and terminal distribution of corticostriatal fibers arising in the sensory-motor cortex of monkeys. J Comp Neurol 173: $53-80$

67. Josiassen RC, Curry LM, Mancall EL (1983) Development of neuropsychological deficits in Huntington's disease. Arch Neurol 40: 791-796

68. Kemp JM, Powell TP (1970) The cortico-striate projection in the monkey. Brain 93: 525-546

69. Kretschmann HJ, Tafesse U, Herrmann A (1982) Different volume changes of cerebral cortex and white matter during histological preparation. Microsc Acta 86: 13-24

70. Kretschmann HJ, Kammradt G, Krauthausen I, Sauer B, Wingert F (1986) Brain growth in man. Bibl Anat 28: 1-26

71. Kuwert T, Lange HW, Langen KJ, Herzog H, Aulich A, Feinendegen LE (1990) Cortical and subcortical glucose consumption measured by PET in patients with Huntington's disease. Brain 113: 1405-1423

72. Künzle H (1975) Bilateral projections from precentral motor cortex to the putamen and other parts of the basal ganglia. Brain Res 88: 195-209

73. Künzle H (1977) Projections from the primary somatosensory cortex to basal ganglia and thalamus in the monkey. Exp Brain Res 30: 481-492

74. Lange H, Thörner G, Hopf A, Schröder KF (1976) Morphometric studies of the neuropathological changes in choreatic diseases. J Neurol Sci 28: 401-425

75. Lange HW (1981) Quantitative changes of telencephalon, diencephalon, and mesencephalon in Huntington's chorea, postencephalitic, and idiopathic parkinsonism. Verh Anat Ges 75: 923-925

76. Lewis DA, Campbell MJ, Terry RD, Morrison JH (1987) Laminar and regional distributions of neurofibrillary tangles and neuritic plaques in Alzheimer's disease: a quantitative study of visual and auditory cortices. J Neurosi 7: 1799-1808

77. Lüers T, Spatz H (1957) Picksche Krankheit (Progressive umschriebene Großhirnatrophie). In: Scholz W (ed) Handbuch der speziellen pathologischen Anatomie und Histologie, vol XIII. Erkrankungen des zentralen Nervensystems, Teil 1/A. Springer, Berlin Göttingen Heidelberg, pp 614-715

78. Maioli MG, Squatrito S, Battaglini PP, Rossi R, Galletti C (1983) Projections from the visual cortical region of the superior temporal sulcus to the striatum and claustrum in the macaque monkey. Arch Ital Biol 121: 259-266

79. Mann DMA, Oliver R, Snowden JS (1993) The topographic distribution of brain atrophy in Huntington's disease and progressive supranuclear palsy. Acta Neuropathol 85: 553-559

80. Marie P, Lhermitte J (1914) Les lésions de la chorée chronique progressive (chorée d' Huntington). La dégéneration atrophique cortico-striée. Ann Med (Paris) 1: 18-47

81. Martin WRW, Clark C, Ammann W, Stoessl AJ, Shtybel W, Hayden MR (1992) Cortical glucose metabolism in Huntington's disease. Neurology 42: 223-229

82. Mayeux R, Stern Y, Rosen J, Benson F (1983) Is "subcortical dementia" a recognizable clinical entity?. Ann Neurol 14: 278-283

83. McCaughey WTE (1961) The pathologic spectrum of Huntington's chorea. J Nerv Ment Dis 133: 91-103

84. McGeorge AJ, Faull RL (1987) The organization and collateralization of corticostriate neurones in the motor and sensory cortex of the rat brain. Brain Res 423: $318-324$

85. Mendez MF, Adams NL, Lewandowski KS (1989) Neurobehavioral changes associated with caudate lesions. Neurology 39: $349-354$

86. Myers RH, Vonsattel JP, Stevens TJ, Cupples LA, Richardson EP, Martin JB, Bird ED (1988) Clinical and neuropathologic assessment of severity in Huntington's disease. Neurology 38 : $341-347$
87. Noth J, Engel L, Friedemann HH, Lange HW (1984) Evoked potentials in patients with Huntington's disease and their offspring. I. Somatosensory evoked potentials. Electroencephalogr Clin Neurophysiol 59: 134-141

88. Oka H (1980) Organization of the cortico-caudate projections. A horseradish peroxidase study in the cat. Exp Brain Res 40: 203-208

89. Pakkenberg B (1992) Stereological quantitation of human brains from normal and schizophrenic individuals. Acta Neurol Scand 85: $20-33$

90. Pakkenberg B (1993) Total nerve cell number in neocortex in chronic schizophrenics and controls estimated using optical dissectors. Biol Psychiatry 34: 768-772

91. Pakkenberg B, Evans SM, Moller A, Braendgaard H, Gundersen HJG (1989) Total number of neurons in human neocortex related to age and sex estimated by way of optical disectors. Acta Stereol 8: 251-256

92. Pillon B, Deweer B, Agid Y, Dubois B (1993) Explicit memory in Alzheimer's, Huntington's, and Parkinson's diseases. Arch Neurol 50: 374-379

93. Price JL, Davis PB, Morris JC, White DL (1991) The distribution of tangles, plaques and related immunohistochemical markers in healthy aging and Alzheimer's disease. Neurobiol Aging 12: 295-312

94. Reale RA, Imig TJ (1983) Auditory cortical field projections to the basal ganglia of the cat. Neuroscience $8: 67-86$

95. Regeur L, Pakkenberg B (1989) Optimizing sampling designs for volume measurements of components of human brain using a stereological method. J Microsc 155: 113-121

96. Reiner A, Albin RL, Anderson KD, D’Amato CJ, Penney JB, Young AB (1988) Differential loss of striatal projection neurons in Huntington disease. Proc Natl Acad Sci USA 85: 5733-5737

97. Reynolds GP, Pearson SJ (1987) Decreased glutamic acid and increased 5-hydroxytryptamine in Huntington's disease brain. Neurosci Lett 78: 233-238

98. Reynolds GP, Pearson SJ, Heathfield KW (1990) Dementia in Huntington's disease is associated with neurochemical deficits in the caudate nucleus, not the cerebral cortex. Neurosci Lett 113: 95-100

99. Richardson EP Jr (1990) Third Dorothy S. Russell memorial lecture. Huntington's disease: some recent neuropathological studies. Neuropathol Appl Neurobiol 16: 451-460

100. Roberts GW, Nash M, Ince PG, Royston MC, Gentleman SM (1993) On the origin of Alzheimers disease - a hypothesis. NeuroReport 4: 7-9

101. Romeis B (1948) Mikroskopische Technik. Oldenbourg, München

102. Rosene DL, Roy NJ, Davis BJ (1986) A cryoprotection method that facilitates cutting frozen sections of whole monkey brains for histological and histochemical processing without freezing artifacts. J Histochem Cytochem 34: 1301-1315

103. Saint-Cyr JA, Ungerleider LG, Desimone R (1990) Organization of visual cortical inputs to the striatum and subsequent outputs to the pallido-nigral complex in the monkey. J Comp Neurol 298: 129-156

104. Salmon DP, Kwo on Yuen PF, Heindel WC, Butters N, Thal LJ (1989) Differentiation of Alzheimer's disease and Huntington's disease with the Dementia Rating Scale. Arch Neurol 46: 1204-1208

105. Scheff SW, Price DA (1993) Synapse loss in the temporal lobe in Alzheimer's disease. Ann Neurol 33: 190-199

106. Schiffer D (1954) Contribution à l'histopathologie de la maladie de Pick. J Hirnforsch 1: 497-515

107. Schröder KF, Hopf A, Lange H, Thörner G (1975) Morphometrisch-statistische Strukturanalysen des Striatum, Pallidum und Nucleus subthalamicus beim Menschen. I. Striatum. J Hirnforsch 16: 333-350

108. Sotrel A, Paskevich PA, Kiely DK, Bird ED, Williams RS, Myers RH (1991) Morphometric analysis of the prefrontal cortex in Huntington's disease. Neurology 41: 1117-1123 
109. Sotrel A, Williams RS, Kaufmann WE, Myers RH (1993) Evidence for neuronal degeneration and dendritic plasticity in cortical pyramidal neurons of Huntington's disease: a quantitative Golgi study. Neurology 43: 2088-2096

110. Spargo E, Everall IP, Lantos PL (1993) Neuronal loss in the hippocampus in Huntington's disease: a comparison with HIV infection. J Neurol Neurosurg Psychiatry 56: 487-491

111. Stanton GB, Goldberg ME, Bruce CJ (1988) Frontal eye field efferents in the macaque monkey. I. Subcortical pathways and topography of striatal and thalamic terminal fields. J Comp Neurol 271: 473-492

112. Starkstein SE, Brandt J, Folstein S, Strauss M, Berthier ML, Pearlson GD, Wong D, McDonnell A, Folstein M (1988) Neuropsychological and neuroradiological correlates in Huntington's disease. J Neurol Neurosurg Psychiatry 51: 1259-1263

113. Stephan H (1960) Methodische Studien über den quantitativen Vergleich architektonischer Struktureinheiten des Gehirns. Z Wiss Zool 164: 143-172

114. Storey E, Beal MF (1993) Neurochemical substrates of rigidity and chorea in Huntington's disease. Brain 116: 1201-1222

115. Tanahashi N, Meyer JS, Ishikawa Y, Kandula P, Mortel KF, Rogers RL, Gandhi S, Walker M (1985) Cerebral blood flow and cognitive testing correlate in Huntington's disease. Arch Neurol 42: 1169-1175

116. Terplan K (1924) Zur pathologischen Anatomie der chronischen progressiven Chorea. Virchows Arch [A] 252: 146-176

117. Topper R, Schwarz M, Podoll K, Domges F, Noth J (1993) Absence of frontal somatosensory evoked potential in Huntington's disease. Brain 116: 87-101
118. van Hoesen GW, Yeterian EH, Lavizzo-Mourey R (1981) Widespread corticostriate projections from temporal cortex of the rhesus monkey. J Comp Neurol 199: 205-219

119. Vogt C, Vogt O (1920) Zur Lehre der Erkrankungen des striären Systems. J Psychol Neurol 25 [Suppl 3]: 631-846

120. Vonsattel JP, Myers RH, Stevens TJ, Ferrante RJ, Bird ED, Richardson EP Jr (1985) Neuropathologic classification of Huntington's disease. J Neuropathol Exp Neurol 44: 559-577

121. Weibel ER (1979) Stereological methods, vol 1. Academic Press, London New York, pp 1-415

122. West MJ (1993) New stereological methods for counting neurons. Neurobiol Aging 14: 275-285

123. West MJ (1993) Regionally specific loss of neurons in the aging human hippocampus. Neurobiol Aging 14: 287-293

124. West MJ, Gundersen HJG (1990) Unbiased stereological estimation of the number of neurons in the human hippocampus. J Comp Neurol 296: 1-22

125. Wiley CA, Masliah E, Morey M, Lemere C, DeTeresa R, Grafe M, Hansen L, Terry R (1991) Neocortical damage during HIV infection. Ann Neurol 29: 651-657

126. Witter MP, Groenewegen HJ (1986) Connections of the parahippocampal cortex in the cat. III. Cortical and thalamic efferents. J Comp Neurol 252: 1-31

127. Yeterian EH, van Hoesen GW (1978) Cortico-striate projections in the rhesus monkey: the organization of certain cortico-caudate connections. Brain Res 139: 43-63

128. Young AB, Penney JB, Starosta-Rubinstein S, Markel DS, Berent S, Giordani B, Ehrenkaufer R, Jewett D, Hichwa R (1986) PET scan investigations of Huntington's disease: cerebral metabolic correlates of neurological features and functional decline. Ann Neurol 20: 296-303 